\title{
Effect of Metalaxyl Resistance and Cultivar Resistance on Control of Phytophthora nicotianae in Tobacco
}

E. van Jaarsveld, Lowveld Tobacco Growers Association, P.O. Box 1158, Nelspruit, 1200, Republic of South Africa; M. J. Wingfield, Tree Pathology Co-operative Program (TPCP), Forestry and Agricultural Biotechnology Institute (FABI), Department of Genetics, Microbiology and Plant Pathology, University of Pretoria, Pretoria, 0002, South Africa; and A. Drenth, Cooperative Research Center for Tropical Plant Pathology, Level 5 John Hines Building, The University of Queensland, Brisbane, Qld 4072, Australia

\begin{abstract}
van Jaarsveld, E., Wingfield, M. J., and Drenth, A. 2002. Effect of metalaxyl resistance and cultivar resistance on control of Phytophthora nicotianae in tobacco. Plant Dis. 86:362-366.

Phytophthora nicotianae is a devastating root and stem pathogen of tobacco (Nicotiana tabacum) in South Africa. Growers strive to control the resulting disease, known as black shank, with metalaxyl treatments and resistant cultivars. The aim of this study was to consider whether development of metalaxyl resistance in P. nicotianae has contributed to poor disease control and if recently developed cultivars with high levels of resistance require metalaxyl for effective control. One hundred and thirty-two isolates of $P$. nicotianae were screened for sensitivity to metalaxyl. P. nicotianae isolates from most tobacco farms were metalaxyl sensitive. Growth of most isolates was inhibited completely at $1.0 \mu \mathrm{g}$ a.i./ml. However, isolates from the MKTV tobacco producing area showed $\mathrm{EC}_{50}$ values ranging from $1.02 \mu \mathrm{g}$ a.i. $/ \mathrm{ml}$ to $3.57 \mu \mathrm{g}$ a.i. $/ \mathrm{ml}$. Twenty-one tobacco cultivars were planted and treated with and without metalaxyl in two different growing seasons to evaluate their resistance to $P$. nicotianae and the value of using metalaxyl. Hicks was the most susceptible cultivar. Vuma/3/46, LK30/40/60-1, and LK33/60 exhibited the greatest resistance to $P$. nicotianae. Use of metalaxyl in combination with moderately resistant cultivars such as NC60 $\times$ TL33 and LK10/80/60 effectively reduced black shank in the field. Resistant cultivars were healthy and no significant difference between metalaxyl treated and untreated plants was observed.
\end{abstract}

Phytophthora nicotianae Breda de Haan (3) is a devastating root and stem pathogen of tobacco (Nicotiana tabacum L.) causing a disease known as black shank. Black shank occurs in most tobacco growing regions in South Africa (18,33). Approximately 25 million $\mathrm{kg}$ of flue and 4.8 million $\mathrm{kg}$ of air-cured tobacco are cultivated annually in the Northern Province (Potgietersrus Co-operative in the Potgietersrus Tabak Koöperasie [PTK] trading area), Mpumalanga (Lowveld Golden Leaf Ltd. in the Lowveld trading area), and NorthWest Province (MKTV Co-operative in the Magaliesburg Koöperatiewe Tabakkwekersvereniging [MKTV] trading area) of South Africa (Fig. 1).

An integrated black shank disease management program is currently being tested in South Africa. This program is aimed at developing black shank resistant tobacco cultivars, improving the use of fungicides against $P$. nicotianae, and implementing crop rotation. This pro-

Corresponding author: E. van Jaarsveld

E-mail: 1tga@lk.co.za

Accepted for publication 12 November 2001.

Publication no. D-2002-0211-01R

(C) 2002 The American Phytopathological Society vitro $(8,25,27)$. The fungicide is a xylemtranslocated phenylamide with systemic apical movement in plants $(5,7)$. Presently, metalaxyl formulations have $71 \%$ of the market share in chemical black shank control in South Africa (SYMPACT J. Brits, Market Information, Crop Product Manager: Subtropical Crops \& Cruiser, Isando, South Africa). Approximately 12 to $20 \%$ of South African tobacco growers use metalaxyl (Ridomil 5G = 50 g a.i./kg) routinely before planting at a concentration of $22 \mathrm{~kg} / \mathrm{ha}$ followed by an additional treatment (11 kg/ha) 4 weeks later (33). Metalaxyl use in tobacco fields has been associated with the appearance of $P$. nicotianae populations with reduced metalaxyl sensitivity in the United States (Georgia, North Carolina), Korea, and Spain $(6,14,16,26)$. In South Africa, metalaxyl was first introduced into tobacco cultivation during 1978 in the PTK trading area. Two years later, growers in the PTK and MKTV trading areas reported poor black shank control. It has been suggested that this lack of control resulted from accelerated biodegradation of the fungicide (1). However, a build up of resistance to metalaxyl in the $P$. nicotianae population may also give rise to poor disease control. The successful use of metalaxyl in the gram also incorporates efficient nematode control (33).

Metalaxyl is used worldwide for the control of many Phytophthora diseases $(23,31)$ including black shank $(13,19)$. Metalaxyl protects tobacco seedlings by inhibiting growth of $P$. nicotianae mycelium and sporangia both in vivo and in

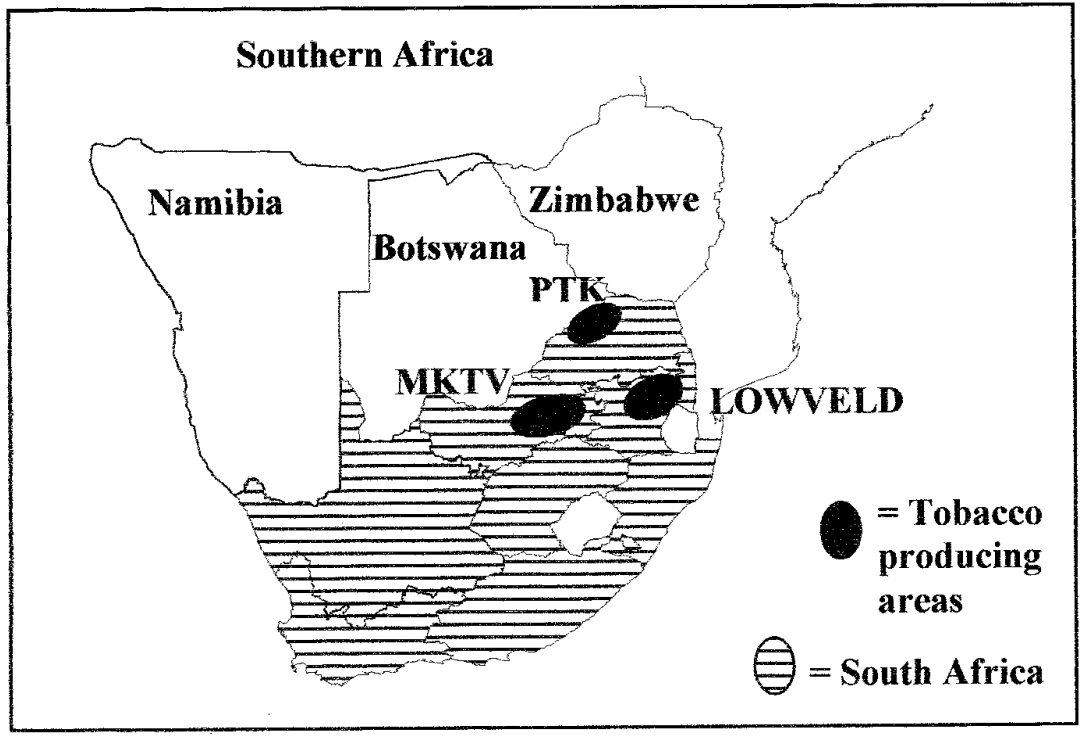

Fig. 1. Map of South Africa showing the different tobacco producing areas. 
Lowveld area over a prolonged period of time may be due to the use of more resistant tobacco cultivars in combination with systematic crop rotation (33). Crop rotation in the Lowveld and the PTK region is implemented by cultivating tobacco for 1 to 2 years successively. Thereafter, the field is planted with a grass crop (Rhodes catambora or Cenchrus ciliaris) for 2 to 4 years successively. In the MKTV trading area, however, tobacco is cultivated every year in the same fields $(18,32)$.

The aim of this study was to determine (i) whether development of metalaxyl resistance in $P$. nicotianae has contributed to poor disease control and (ii) if recently developed tobacco cultivars with high levels of resistance give better disease control under field conditions in combination with the use of metalaxyl. The outcome of this study would provide useful information to aid implementing an economically viable metalaxyl management program in South Africa.

\section{MATERIALS AND METHODS}

Metalaxyl resistance in vitro. One hundred and thirty-two $P$. nicotianae isolates were collected from tobacco farms in the PTK, MKTV, and the Lowveld areas in South Africa, as well as from Zimbabwe with 19, 26, 82, and 5 isolates collected, respectively (Table 1 ). Eighty-nine $P$. nicotianae isolates were obtained from the soil by baiting with citrus leaves (11). Fortythree $P$. nicotianae isolates were isolated from infected roots and stem tissues of tobacco plants that were surface sterilized in $70 \%$ ethanol and then placed on selective PARPH medium (30). Cultures were examined for growth of $P$. nicotianae after 3 days and isolates were identified as $P$. nicotianae based on morphology. The cultures have been deposited in the culture collections of the Forestry and Agricultural Biotechnology Institute (FABI) (CMW 6913-7013 and CMW 7906-7938), University of Pretoria, RSA and the Cooperative Research Center for Tropical Plant Pathology, University of Queensland (UQ5253-UQ5373 and UQ5416-UQ5443), Australia.
P. nicotianae isolates were evaluated for their resistance to metalaxyl based on $50 \%$ growth rate inhibition $\left(\mathrm{EC}_{50}\right)$. The Ridomil 480 EC formulation (Novartis South Africa) was used to obtain fungicide concentrations of $0.01,0.1,1.0$, and $10.0 \mu \mathrm{g}$ a.i./ml (6). Metalaxyl was added to cool $45^{\circ} \mathrm{C}$ potato dextrose agar (PDA; Biolab, Midrand, South Africa) medium and $12 \mathrm{ml}$ of medium was poured per $65 \mathrm{~mm}$ petri plate. A 5-mm-diameter disk was cut from the margin of each fungal isolate growing on PDA for 5 days in the dark at $27^{\circ} \mathrm{C}$. Each disk was transferred to the center of an agar plate. Control plates contained only PDA. There were three replicates per isolate at each metalaxyl concentration. Mycelial growth was recorded to the nearest millimeter along the longest radius after 6 days of incubation in the dark at $27^{\circ} \mathrm{C}$ (26). Average colony diameters were calculated for each isolate at each fungicide concentration. These values were used to calculate $\mathrm{EC}_{50}$ values with the Half-Maximal Response curve for estimating responsiveness in STATISTICA (Statistica, 1993, Statistica for WindowsVersion 4.5B Statsoft Inc., Tulsa, OK). Each average diameter reading was converted into the percentage of growth inhibited as compared to the control by calculating the difference in the growth between each fungicide concentration, and a curve fitted by STATISTICA. The following equation of the curve was used:

$$
Y=b_{0}-b_{0} /\left[1+\left(x / b_{2}\right)^{b 1}\right]
$$

where $b_{0}$ is the expected response at saturation, $b_{1}$ determines the slope of the function, and $b_{2}$ is the concentration for a half maximal response. The start value for $b_{0}$ was the percent inhibition at the highest concentration of metalaxyl for each isolate. Parameter estimates b0, b1 and b2 were calculated by STATISTICA. The concentration at which growth was inhibited by $50 \%\left(\mathrm{EC}_{50}\right)$ was calculated by substituting $y=50$ into the above equation and solving for $x$ using the parameter estimates. The trial was repeated once.

The effectiveness of metalaxyl and cultivar resistance under field condi- tions. The field tests were conducted in a naturally infested area with an 8-year history of black shank on the farm Barberton Boere (Table 1). After severe hail in the 1997 tobacco season, plants were trimmed back and suckers selected for growth of new leaves. However, approximately 80 to $90 \%$ of the plants died of black shank at this site, thus severe black shank occurred over the whole test area. Field tests (1998 and 1999) were conducted at this site for two consecutive years. Seedling production, fertilization, cultivation, insect control, and sucker control followed the Lowveld Tobacco Growers' Association Extension recommendations $(20,22)$. Seedlings were treated with Apron 35 SD (metalaxyl $350 \mathrm{~g}$ a.i. $/ \mathrm{kg}$ ) applied at 35 $\mathrm{g} / 100$ liter water before transplanting, thus protecting seedlings from Pythium and Phytophthora species for approximately 4 weeks after planting (1). Plots were irrigated as required. The area was plowed and soil thoroughly mixed after each tobacco season. Tobacco cultivars used in this study originated from Zimbabwe (T20, Mammoth 10, AW, and MS WZ), North Carolina (Speight G-108, Coker 371-Gold, K149, MDH, and Hicks), and South Africa (B40/108, NC60 $\times$ TL33, Vuma, Vuma $\times$ Coker371-Gold, LK10/80/60, LK3/46, LK30/40/60-1 (selection), LK33/60, LK80/60/60, LK3/46/Vuma, LK30/40/60-2 (selection), and Vuma/3/46.

Twenty-one tobacco cultivars were planted in combination with or without metalaxyl to evaluate fungicide-cultivar combinations as treatments for control of tobacco black shank. The field trial consisted of 42 treatments in a complete randomized block design with four replicates in 1-row plots with 20 plants each. The treatment rows were separated by skip rows that were planted with susceptible Hicks plants to ensure continuous inoculum. Plants were spaced $50 \mathrm{~cm}$ apart within rows and rows were $1.3 \mathrm{~m}$ apart. The treatments were 21 tobacco cultivars planted in combination with or without metalaxyl. The metalaxyl treatments received $22 \mathrm{~kg} / \mathrm{ha}(50 \mathrm{~g}$ a.i. $/ \mathrm{kg}$ ) metalaxyl (Ridomil 5G) applied preplant to soil and

Table 1. The range and mean metalaxyl $\mathrm{EC}_{50}$ for 132 farm isolates of Phytophthora nicotianae

\begin{tabular}{|c|c|c|c|c|c|c|}
\hline \multirow[b]{2}{*}{ Area } & \multirow[b]{2}{*}{ Site } & \multirow[b]{2}{*}{ Farm } & \multirow[b]{2}{*}{ Number of isolates } & \multicolumn{3}{|c|}{ Metalaxyl $\mathrm{EC}_{50}{ }^{\mathrm{a}}$} \\
\hline & & & & Min & Max & Mean \\
\hline \multirow{5}{*}{ Lowveld } & Karino & Barberton Boere & 12 & 0.01 & 0.15 & 0.06 \\
\hline & & Friedenheim & 45 & 0.00 & 0.32 & 0.04 \\
\hline & Barberton & Dave Cooper & 16 & 0.00 & 0.46 & 0.08 \\
\hline & Schagen & Oos Wes Boerdery & 3 & 0.03 & 0.12 & 0.06 \\
\hline & & LTGA farm & 6 & 0.02 & 0.14 & 0.06 \\
\hline \multirow[t]{3}{*}{ MKTV } & Rustenburg & Roelf Otterman & 17 & 0.07 & 3.57 & 0.46 \\
\hline & & Research Institute for Tobacco and Cotton & 7 & 0.03 & 0.94 & 0.26 \\
\hline & Naboomspruit & A. Botha & 2 & 0.01 & 0.14 & 0.07 \\
\hline \multirow[t]{2}{*}{ PTK } & Potgietersrus & De Wet Roos & 14 & 0.00 & 0.63 & 0.06 \\
\hline & Levubu & A. Botha & 5 & 0.03 & 0.09 & 0.06 \\
\hline Zimbabwe & & Kutsaga & 5 & 0.00 & 0.57 & 0.15 \\
\hline Total & & & 132 & 0.0001 & 3.565 & 0.123 \\
\hline
\end{tabular}

${ }^{\mathrm{a}} \mathrm{EC}_{50}$ is in $\mu \mathrm{g}$ a.i. $/ \mathrm{ml}$. 
incorporated at a depth of $20 \mathrm{~cm}$. Cultivars planted without metalaxyl did not receive any chemical treatment and served as controls. Nematodes were controlled with Aldicarb (Temik 15G) applied at $20 \mathrm{~kg} / \mathrm{ha}$ with planting. Plants were examined weekly, starting 6 weeks after planting until all leaves had been harvested. Diseased plants were counted and marked at the first signs of black shank symptoms. The number of diseased plants and the time of symptom development were used to calculate disease indices (12). The disease index (DI) was calculated using the following formula:

$$
\mathrm{DI}=\left[\left(\Sigma_{i=1-7 n} n \cdot w i / N\right)\right] \times 100
$$

where $n=$ number of diseased plants for weeks 1 to $7, w=$ value given for the time of disease onset, $w=1$ to 7 (week $1=7$, week $2=6$, week $3=5$, week $4=4$, week $5=3$, week $6=2$, week $7=1$ ), $N=$ total number of plants multiplied by the maximum value $(w=7)$. Plants were considered diseased when the leaves were permanently wilted, stunted, and a black lesion appeared at the base of the stem. A disease index of 0 indicated no detectable level of disease while that of 100 indicated that all plants had died within the 7 -week period.
The entire trial was conducted in two consecutive years. Data were statistically analyzed for differences among cultivars and metalaxyl treatments. Means were tested for significance using Tukey's procedure (28).

\section{RESULTS}

Metalaxyl resistance in vitro. The range of $P$. nicotianae resistance to metalaxyl was determined for individual farms (Table 1). Results showed that the $P$. nicotianae populations from most tobacco farms exhibited low $\mathrm{EC}_{50}$ values and were, therefore, predominantly sensitive to metalaxyl. Growth of most isolates was inhibited completely at $1.0 \mu \mathrm{g}$ a.i./ml. However, two isolates from the Roelf Otterman farm were slightly resistant to metalaxyl compared to other MKTV isolates $\left(\mathrm{EC}_{50}=3.57 \mu \mathrm{g}\right.$ a.i. $/ \mathrm{ml}$ and $1.02 \mu \mathrm{g}$ a.i./ml). An isolate from the Research Institute for Tobacco and Cotton was also slightly resistant to metalaxyl $\left(\mathrm{EC}_{50}=0.94\right.$ $\mu \mathrm{g}$ a.i./ml) compared to other isolates included in this study.

The mean $\mathrm{EC}_{50}$ values in the Lowveld and PTK area ranged from 0.04 to $0.08 \mu \mathrm{g}$ a.i./ml while mean $\mathrm{EC}_{50}$ values in the MKTV area ranged from 0.07 to $0.46 \mu \mathrm{g}$

Table 2. Comparison of disease indices linked to susceptibility to Phytophthora nicotianae for 21 tobacco cultivars grown - with and without metalaxyl

\begin{tabular}{|c|c|c|c|c|}
\hline \multirow[b]{3}{*}{ Cultivars } & \multicolumn{4}{|c|}{ Disease index ${ }^{a}$} \\
\hline & \multicolumn{2}{|c|}{1998} & \multicolumn{2}{|c|}{1999} \\
\hline & $\begin{array}{c}\text { Without } \\
\text { metalaxyl }\end{array}$ & $\begin{array}{c}\text { With } \\
\text { metalaxyl }\end{array}$ & $\begin{array}{c}\text { Without } \\
\text { metalaxyl }\end{array}$ & $\begin{array}{c}\text { With } \\
\text { metalaxyl }\end{array}$ \\
\hline \multicolumn{5}{|l|}{ Susceptible } \\
\hline Hicks & $85.4 \mathrm{cc}^{\mathrm{b}}$ & $73.8 \mathrm{z}-\mathrm{bb}$ & $86.4 \mathrm{LL}^{\mathrm{c}}$ & 69.3 GG-JJ \\
\hline AW & $67.9 \mathrm{x}-\mathrm{z}$ & 66.4 xy & $80.3 \mathrm{KKLL}$ & $66.5 \mathrm{GG}$ \\
\hline MS WZ & $70.0 \mathrm{x}-\mathrm{aa}$ & $64.0 \mathrm{x}^{\circ}$ & 74.4 GG-KK & $66.7 \mathrm{GGHH}$ \\
\hline Mammoth 10 & $56.8 \mathrm{w}$ & $46.7 \mathrm{v}$ & 67.2 GG-II & 35.0 EEFF \\
\hline \multicolumn{5}{|l|}{ Moderately resistant } \\
\hline NC60 × TL33 & $29.6 \mathrm{u}$ & $4.4 \mathrm{a}-\mathrm{k}$ & 29.0 AA-EE & $4.5 \mathrm{~A}-\mathrm{G}$ \\
\hline Vuma & $22.8 \mathrm{st}$ & 14.7 p-r & $22.9 \mathrm{~W}-\mathrm{CC}$ & 14.4 M-V \\
\hline LK10/80/60 & $16.5 \mathrm{q}-\mathrm{s}$ & $6.0 \mathrm{a}-\mathrm{m}$ & $16.6 \mathrm{~N}-\mathrm{Y}$ & $6.1 \mathrm{~A}-\mathrm{L}$ \\
\hline T20 & $6.6 \mathrm{a}-\mathrm{n}$ & $0.6 \mathrm{a}-\mathrm{c}$ & $22.7 \mathrm{~V}-\mathrm{BB}$ & 15.1 M-X \\
\hline Vuma $\times$ Coker $371-$ Gold & $8.1 \mathrm{f}-\mathrm{p}$ & $6.6 \mathrm{a}-\mathrm{n}$ & $19.3 \mathrm{~S}-\mathrm{Z}$ & $9.3 \mathrm{C}-\mathrm{N}$ \\
\hline LK3/46 & $12.3 \mathrm{~m}-\mathrm{q}$ & $5.2 \mathrm{a}-1$ & 26.2 Z-DD & $21.9 \mathrm{~V}-\mathrm{AA}$ \\
\hline \multicolumn{5}{|l|}{ Highly resistant } \\
\hline $\mathrm{MDH}$ & $0.3 \mathrm{ab}$ & $3.8 \mathrm{a}-\mathrm{i}$ & $15.0 \mathrm{M}-\mathrm{W}$ & 10.2 D-R \\
\hline Speight G-108 & $1.3 \mathrm{a}-\mathrm{e}$ & $1.6 \mathrm{a}-\mathrm{f}$ & $13.0 \mathrm{H}-\mathrm{U}$ & 5.4 A-I \\
\hline Coker371-Gold & $4.1 \mathrm{a}-\mathrm{j}$ & $6.9 \mathrm{~b}-\mathrm{o}$ & $9.6 \mathrm{C}-\mathrm{O}$ & 9.7 C-P \\
\hline LK30/40/60-1 & $0.9 \mathrm{a}-\mathrm{d}$ & $0.0 \mathrm{a}$ & 6.9 A-M & $4.9 \mathrm{~A}-\mathrm{H}$ \\
\hline LK33/60 & $0.3 \mathrm{ab}$ & $0.9 \mathrm{a}-\mathrm{d}$ & $11.4 \mathrm{~F}-\mathrm{T}$ & 5.6 A-J \\
\hline LK80/60/60 & $1.3 \mathrm{a}-\mathrm{e}$ & $0.0 \mathrm{a}$ & 9.8 D-P & $10.0 \mathrm{D}-\mathrm{Q}$ \\
\hline LK3/46/Vuma & $3.4 \mathrm{a}-\mathrm{h}$ & $1.9 \mathrm{a}-\mathrm{g}$ & 5.8 A-K & 3.0 A-E \\
\hline LK30/40/60-2 & $1.9 \mathrm{a}-\mathrm{g}$ & $0.0 \mathrm{a}^{\circ}$ & $11.1 \mathrm{E}-\mathrm{S}$ & $4.3 \mathrm{~A}-\mathrm{F}$ \\
\hline B40/108 & $0.3 \mathrm{ab}$ & $0.0 \mathrm{a}$ & $2.4 \mathrm{~A}-\mathrm{D}$ & $0.5 \mathrm{AB}$ \\
\hline Vuma/3/46 & $0.6 \mathrm{ac}$ & $0.0 \mathrm{a}$ & $1.5 \mathrm{~A}-\mathrm{C}$ & $0.0 \mathrm{~A}$ \\
\hline K149 & $0.3 \mathrm{ab}$ & $0.0 \mathrm{a}$ & $0.5 \mathrm{AB}$ & $0.0 \mathrm{~A}$ \\
\hline
\end{tabular}

a The disease index was calculated using the formula: $\mathrm{DI}=\left[\left(\sum_{i=1-7} n \cdot w i / N\right)\right] \times 100$ Where $n=$ number of diseased plants for weeks 1 to $7, w=$ value given for the time of disease onset $w=1$ to 7 (week $1=7$, week $2=6$, week $3=5$, week $4=4$, week $5=3$, week $6=2$, week $7=1$ ), $N=$ total number of plants multiplied with the maximum value $(w=7)$. A disease index of 0 indicated no detectable level of disease while that of 100 indicated that all plants had died within the 7-week period. Each value represents the mean of four replicates.

b Within columns for the 1998 season, values followed by the same letter are not significantly different according to Tukey's LSD $(0.05)=6.72$.

c Within columns for the 1999 season, values followed by the same letter are not significantly different according to Tukey's LSD $(0.05)=8.22$. a.i./ml (Table 1). P. nicotianae isolates from the MKTV appear in general to be slightly more resistant to metalaxyl than isolates from the Lowveld and PTK areas.

The effectiveness of metalaxyl and cultivar resistance under field conditions. High levels of black shank developed in the field as shown by the reaction of the susceptible cultivar Hicks in the skip rows (data not shown) and trials (Table 2). Susceptible plants exhibited black shank symptoms as early as 6 to 7 weeks after planting and included stunting, wilting, and tissue discoloration at the base of the stem. Leaves of plants infected later in the season (10 weeks after planting) turned yellow, wilted, and eventually displayed leafbronzing symptoms. Susceptible plants died before topping (week 9 after planting). Leaves of these plants were immature and could not be harvested. In contrast, most leaves of resistant plants developed normally and were successfully harvested.

Significant differences $\left(\mathrm{LSD}_{1998} 0.05=\right.$ 6.72, $\mathrm{LSD}_{1999} 0.05=8.22$ ) were found in cultivar resistance as reflected by disease indices (Table 2). Hicks had the greatest disease index since 85.4 and $86.4 \%$ of the plants showed black shank symptoms at the end of the 1998 and 1999 seasons when not treated with metalaxyl. The Lowveld cultivars Vuma/3/46, LK30/40/60-1, and LK33/60 had high levels of resistance to $P$. nicotianae with disease indices ranging from 0.3 to $0.9 \%$ for the 1998 season and 1.5 to $11.4 \%$ for the 1999 season. Cultivars with moderate resistance to $P$. nicotianae included NC60 $\times$ TL33 (29 to 29.6\%), Vuma (22.8 to $22.9 \%$ ), and Vuma $\times$ Coker371-Gold (8.1 to $19.3 \%$ ). The North Carolina cultivars Speight G-108 (1.3 to $13 \%$ ) and Coker 371-Gold (4.1 and 9.6\%) exhibited high degrees of resistance to $P$. nicotianae. The low disease index values obtained for Vuma $\times$ Coker 371-Gold and Coker 371-Gold, known for its resistance to race 0 and susceptibility to race $1(4,15)$, suggest the presence of race 0 of $P$. nicotianae at this locality. This is in agreement with previous reports of the occurrence of race 0 in the Lowveld region (17).

The application of metalaxyl improved the performance of most susceptible and moderately resistant cultivars. The use of a single metalaxyl application resulted in significantly $\left(\mathrm{LSD}_{1998} 0.05=6.72, \mathrm{LSD}_{1999}\right.$ $0.05=8.22$ ) lower disease indices (Table 2). Examples include NC60 × TL33 (4.4\%) and LK10/80/60 (6\%) that are moderately resistant and had disease rates of 29.6 and $16.5 \%$, respectively, without treatment. Similarly, the susceptible cultivar Mammoth 10 (35 to $46.7 \%$ ) had disease index rates of 56.8 to $67.2 \%$ without metalaxyl (Table 2). Cultivars such as Vuma/3/46 (0.6 to $1.5 \%)$, LK30/40/60-1 (0.9 to 6.9\%), $\mathrm{MDH}(0.3$ to $15 \%)$, and $\mathrm{K} 149$ (0.3 to 0 . $5 \%$ ) with high resistance to black shank did not show significant $\left(\mathrm{LSD}_{1998} 0.05=\right.$ 6.72, $\mathrm{LSD}_{1999} 0.05=8.22$ ) differences in 
disease indices between metalaxyl treated and untreated plants.

\section{DISCUSSION}

Mean $\mathrm{EC}_{50}$ values for $P$. nicotianae isolates examined in this study were within the ranges previously reported for $P$. nicotianae isolates from tobacco $(0.01 \mu \mathrm{g}$ a.i./ml to $1.2 \mu \mathrm{g}$ a.i./ml $)(6,26)$ except for one isolate which had an $\mathrm{EC}_{50}$ value of $3.57 \mu \mathrm{g}$ a.i. $/ \mathrm{ml}$. Our survey revealed that most $P$. nicotianae populations from the investigated farms in South Africa are currently sensitive to metalaxyl. An exception was found in the MKTV area where two isolates had $\mathrm{EC}_{50}$ values of $1.02 \mu \mathrm{g}$ a.i./ml and $3.57 \mu \mathrm{g}$ a.i./ml. Previous authors $(6,26)$ also reported $\mathrm{EC}_{50}$ values of $1.0 \mu \mathrm{g}$ a.i./ml and $1.2 \mu \mathrm{g}$ a.i./ml for slightly resistant $P$. nicotianae isolates. Higher $\mathrm{EC}_{50}$ values for metalaxyl resistance have, however, been reported for $P$. nicotianae from other hosts such as citrus $(100 \mu \mathrm{g}$ a.i./ml) and periwinkle (742.4 $\mu \mathrm{g}$ a.i./ml) $(9,29)$.

Studies conducted by Shew (26) with 877 isolates have shown that continuous application of metalaxyl to field soils infested with $P$. nicotianae resulted in an increase in the $\mathrm{EC}_{50}$ values from 0.4 to 1.2 ug a.i./ml within 3 years. The high $\mathrm{EC}_{50}$ values on the farms Research Institute for Tobacco \& Cotton and Roelf Otterman (MKTV trading area) in comparison to other tobacco areas in South Africa reflects the longer and more intensive use of metalaxyl on the farms. These findings are in agreement with the practice of using metalaxyl every year at the Research Institute for Tobacco \& Cotton and the Roelf Otterman farm (MKTV trading area) in comparison with metalaxyl use every 2 to 3 years on the farms Barberton Boere, Dave Cooper, Oos Wes Boerdery, and the LTGA farm in the Lowveld trading area (personal communication with growers). Although this study was limited in sample size (26 isolates) from the MKTV area, this result indicates that a decline in metalaxyl sensitivity may have contributed to poor control of black shank.

The occurrence of slight metalaxyl resistance in South Africa appears to be relatively localized, however, $P$. nicotianae can reproduce very rapidly and metalaxyl resistance in several Phytophthora spp. is inherited as a single incomplete dominant gene $(2,10,24)$. Previous studies found that many metalaxyl resistant $P$. nicotianae isolates are inherently fit, virulent, and can compete with sensitive isolates $(9,29)$. Furthermore, Timmer et al. (29) found that a high percentage of a $P$. nicotianae population remained resistant after 2.5 years without treatment.

Cultivation of susceptible tobacco cultivars in monoculture combined with the continuous use of metalaxyl in South Africa is likely to select for $P$. nicotianae isolates less sensitive to metalaxyl as re- ported in Georgia and North Carolina $(6,26)$. There is no known method for complete eradication of $P$. nicotianae in the field, and future monitoring of these populations is required to determine whether metalaxyl resistant isolates become more widespread.

Results of this study showed that the use of metalaxyl significantly reduced disease indices thereby improving survival of susceptible and moderately resistant cultivars. This is consistent with findings of Reilly (19) who also showed that the use of metalaxyl was most effective on tobacco cultivars with little resistance to black shank. For example, a single metalaxyl application in the 1998 season reduced disease incidences of susceptible cultivars such as Mammoth 10 from 56.8 to $46.7 \%$ and Hicks from 85.4 to $73.8 \%$.

In this study, highly resistant cultivars such as Vuma/3/46, LK30/40/60, and LK33/60 had low disease indices indicating that plants were healthy and few plants developed black shank symptoms. No significant differences were found between disease indices when resistant plants received a single metalaxyl application. The availability of highly resistant cultivars such as Vuma/3/46, LK30/40/60-1, and LK33/60 to growers provides an opportunity for more effective and economical black shank management. These resistant cultivars have been approved in terms of quality and yield by the tobacco trade in South Africa (21). Various factors are required for improved black shank control and increased durability of cultivar resistance. Continued monitoring for spread or increased frequency of $P$. nicotianae isolates with metalaxyl resistance must be a key component of this process. Likewise, it will be important for South African tobacco farmers to use metalaxyl selectively and together with moderately resistant cultivars. The use of highly resistant cultivars, which do not need to be treated with metalaxyl, should be promoted. Efforts to improve the durability of disease resistance in tobacco cultivars through rotation of cultivars carrying different forms of resistance, as well as improvements in drainage and soil health will be key factors in reducing the impact of this important disease.

\section{ACKNOWLEDGMENTS}

We acknowledge financial support from Coresta (Cooperation Center for Research relative to Tobacco), Lowveld Golden Leaf Ltd. and the University of Pretoria. Special thanks to Barbara Sendall for help with the $\mathrm{EC}_{50}$ calculations.

\section{LITERATURE CITED}

1. Anonymous. 1999. Novartis Label Book. Novartis South Africa (PTY) LTD Crop Protection Sector.

2. Bhat, R. G., McBlain, B. A., and Schmitthener, A. F. 1993. The inheritance of resistance to metalaxyl and to fluorophenylalanine in matings of homothallic Phytophthora sojae. Mycol. Res. 97:865-870.

3. Breda de Haan, J. van, 1896. De bibitzieke in de Deli tabak veroorsaakt door Phytophthora nicotianae (The root disease in Deli-tobacco caused by Phytophthora nicotianae). Meded. 'S. Lands Plantentium 15.

4. Carlson, S. R., Wolff, M. F., Shew, H. D., and Wernsman, E. A. 1997. Inheritance of resistance to race 0 of Phytophthora parasitica var. nicotianae from the flue-cured tobacco cultivar Coker 371-Gold. Plant Dis. 81:12691274.

5. Cohen, Y., and Coffey, M. D. 1986. Systemic fungicides and the control of Oomycetes. Annu. Rev. Phytopathol. 24:311-339.

6. Csinos, A. S., and Bertrand, P. F. 1994. Distribution of Phytophthora parasitica var. nicotianae races and their sensitivity to metalaxyl in Georgia. Plant Dis. 78:471-474.

7. Edgington, L. V., and Peterson, C. A. 1977. Systemic fungicides: theory, uptake and translocation. Pages 51-89 in: Antifungal compounds Vol 2. M. R. Siegel and H. D. Sisler, eds. Marcel Dekker, New York.

8. Farih, A., Tsao, P. H., and Menge, J. A. 1981 Fungitoxic activity of efosite aluminium on growth, sporulation, and germination of $P h y$ tophthora parasitica and $P$. citrophthora. Phytopathology 71:934-936.

9. Ferrin, D. M., and Kabashima, J. N. 1991. In vitro insensitivity to metalaxyl of isolates of Phytophthora citricola and P. parasitica from ornamental hosts in Southern California. Plant Dis. 75:1041-1044.

10. Goodwin, S. B., and McGrath, M. T. 1995. Insensitivity to metalaxyl among isolates of Phytophthora erythroseptica causing pink rot of potato in New York. Plant Dis. 79:967.

11. Grimm, G. R., and Alexander, A. 1973. Citrus leaf pieces as traps for Phytophthora parasitica from soil slurries. Phytopathology 63:540-541.

12. Jack, A., and Robertson, A. 1997. The Coresta collaborative study on bacterial wilt (Ralstonia solanacearum) - 1997 Report. Tobacco Research Board, Harare, Zimbabwe.

13. Kannwisher, M. E., and Mitchell, D. J. 1978. The influence of a fungicide on the epidemiology of black shank on tobacco. Phytopathology 68:1760-1765.

14. Kim, J. H., and Kang, Y. K. 1997. Screening alternative fungicides to control metalaxyl resistant Phytophthora parasitica var. nicotianae in Korea. Inf. Bull. Coresta 2:128.

15. Legg, P. D., and Smeeton, B. W. 1999. Breeding and Genetics. Pages 32-48 in: Tobacco Production, Chemistry and Technology. D. L. Davis, and M. T. Nielsen, eds. Blackwell Science Ltd., Oxford.

16. Muino, B., Diaz, I., and Jaenz, A. 1990. Evidence of resistance against metalaxyl of strains of Phytophthora parasitica var. nicotianae in tobacco areas of Pinar de Rio province. Cienc. Tec. Agric. Tabaco 13-2:59-67.

17. Nielsen, M. T. 1995. Collaborative Study on Black Shank 1995 Report. Inf. Bull. Coresta 2:31-34.

18. Prinsloo, G. C. 1994. Black shank of tobacco in the Republic of South Africa. (Abstr.) Page 89 in: Coresta Congress 1994, Harare, Zimbabwe.

19. Reilly, J. J. 1980. Chemical control of black shank of tobacco. Plant Dis. 64:274-277.

20. Scholtz, A. 1992. Cultivar development. Kaleidoscope of Tobacco, a publication of the Lowveld Tobacco Growers Association 1:3039.

21. Scholtz, A. 2000. LTGA Research Report Cultivar Development 1999/2000. Lowveld Tobacco Growers Association, P.O. Box 60, Nelspruit, 1200, South Africa.

22. Scholtz, A., Sonnenberg, S. M., and Smith, P. J. 1998. Production of tobacco seedlings in pine-bark medium on permanent seedbed structures - the use of steam sterilization as opposed to methyl bromide. (Abstr.) Page 82 
in: Coresta Congress 1998, Brighton, England.

23. Schwinn, F. J. 1983. New development in chemical control of Phytophthora. Pages 327334 in: Phytophthora: Its Biology, Taxonomy, Ecology, and Pathology. D. C. Erwin, S. Bartnicki-Garcia, and P. H. Tsao, eds. The American Phytopathological Society, St. Paul, MN.

24. Shattock, R. C. 1988. Studies on the inheritance of resistance to metalaxyl in Phytophthora infestans. Plant Pathol. 37:4-11.

25. Shew, H. D. 1984. In vitro response of Phytophthora parasitica var. nicotianae isolates to metalaxyl. Plant Dis. 68:764-766.

26. Shew, H. D. 1985. Response of Phytophthora parasitica var. nicotianae to metalaxyl exposure. Plant Dis. 69:559-562.

27. Staub, T. H., and Young T. R. 1980. Fungitoxicity of metalaxyl against Phytophthora parasitica var. nicotianae. Phytopathology 70:797-801.

28. Steel, R. G. D., and Torrie, J. H. 1980. Principles and Procedures for Statistics. 2nd ed. McGraw-Hill, New York.

29. Timmer, L. W., Graham, J. H., and Zitko, S. E. 1998. Metalaxyl-resistant isolates of Phytophthora nicotianae: occurrence, sensitivity, and competitive parasitic ability on citrus. Plant Dis. 82:254-261.

30. Tsao, P. H., and Guy, S. O. 1977. Inhibition of
Mortierella and Pythium in a Phytophthoraisolation medium containing hymexazol. Phytopathology 67:796-801.

31. Urech, P. A., Schwinn, F., and Staub, T. 1977. CGA 48988, a novel fungicide for the control of late blight, downy mildews and related soilborne diseases. Proc. Br. Crop Prot. Conf 42:623-631.

32. Van der Linde, G. E. 1992. Nematode Control. Kaleidoscope of Tobacco, a publication of the Lowveld Tobacco Growers Association 1:23-28.

33. Van Jaarsveld, E. 1995. Black Shank. Kaleidoscope of Tobacco, a publication of the Lowveld Tobacco Growers Association 1:20-28. 